\title{
Peuyeum: fermented cassava from Bandung, West Java, Indonesia
}

\author{
Laras Cempaka(1)
}

\begin{abstract}
Peuyeum is a fermented cassava product from Indonesia. Peuyeum or cassava tapay is known as "Peuyeum Bandung," whose name refers to a provincial capital in West Java, Java Island. Peuyeum is processed through fermentation and uses starter cultures in the form of yeast tapay. The word peuyeum comes from "meuyeum" or "memeram," which in Sundanese-the native language of West Java-means an incubation. This is because the process to make it requires curing time for ripening. The cassava is peeled, cleaned, and boiled to soften the tissue, then the starter is added and incubated for a certain time. The skill of making peuyeum is a generational one, passed down so that this traditional food is still preserved, even though it has become the local specialty of West Java. Derivative products are now increasingly diverse, which are fried tapay, colenak (grilled peuyeum served with a mixture of brown sugar and coconut shavings), mixed fruit ice, peuyeum cake, and others. In fact, for all the abovementioned cuisines, it can be said that fermentation was applied in producing the various traditional food items. Philosophically, peuyeum represents societies, group solidarity, peace of mind, and language symbolism. Thus, this paper discusses the history, philosophy, process, and derivative products of peuyeum.
\end{abstract}

Keywords: Bandung, Cassava, Fermented food, Peuyeum, Tapay

\section{Introduction}

Peuyeum or cassava tapay is a fermented product made from cassava. Indonesia is recognized as one of the producers of tubers, including cassava, sweet potato, taro, potato, and so on [1]. These tubers can be processed by boiling, steaming, frying, fermenting, or mixing with other food ingredients such as cakes, cookies, or snacks. Cassava is an agricultural commodity and is widely grown in Indonesia as a source of carbohydrates and energy. In some areas, cassava (Manihot utillisima) is consumed as a staple food or used as a substitute for rice [2]. One of the cassava derivative products originating from Indonesia is peuyeum or fermented cassava. Peuyeum has a distinctive aroma, taste, and soft texture [3] and is made through a fermentation process by adding starter cultures.

Correspondence: laras.cempaka@bakrie.ac.id

Department of Food Science and Technology, Universitas Bakrie, JI. H.R.

Rasuna Said, Kav. C-22, Kuningan, 12920 South Jakarta, Indonesia
The culture involves not only yeast but also a consortium of microbes such as molds and bacteria. The shape of the starters is round and flat (Fig. 1). Local people prefer the term ragi tape or yeast tapay-ragi tape is used as a general term in society, while yeast tapay emerged because the people recognized its alcoholic taste. This alcohol is a metabolite and produced by the Saccharomyces cerevisiae. The basic of the process is the degradation of starch components into dextrin and glucose, after which the glucose is converted into alcohol or acid so that the fermentation process is slightly sour or sweet with an alcoholic taste. The quality of peuyeum depends on the quality of the base material, the method of manufacture, and the microbial content $[4,5]$. This paper explains the history of peuyeum, its philosophy that impacts society, and the traditional process of making peuyeum, associated with the culture and fermentation processes, and discusses some examples of derivative products commonly known by the public.

(c) The Author(s). 2021 Open Access This article is licensed under a Creative Commons Attribution 4.0 International License, which permits use, sharing, adaptation, distribution and reproduction in any medium or format, as long as you give appropriate credit to the original author(s) and the source, provide a link to the Creative Commons licence, and indicate if changes were made. The images or other third party material in this article are included in the article's Creative Commons licence, unless indicated otherwise in a credit line to the material. If material is not included in the article's Creative Commons licence and your intended use is not permitted by statutory regulation or exceeds the permitted use, you will need to obtain permission directly from the copyright holder. To view a copy of this licence, visit http://creativecommons.org/licenses/by/4.0/. 


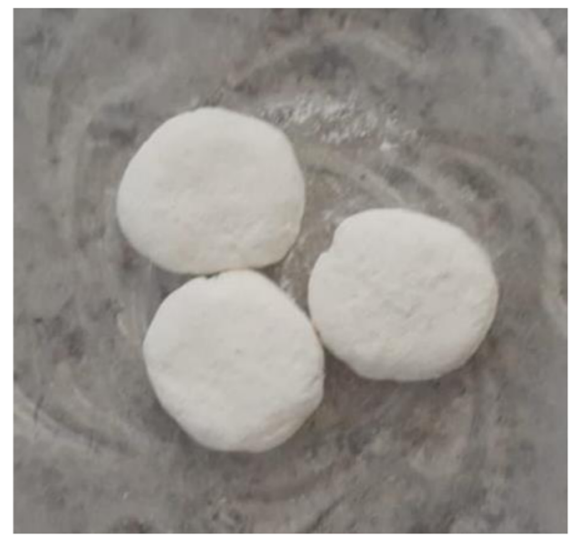

a

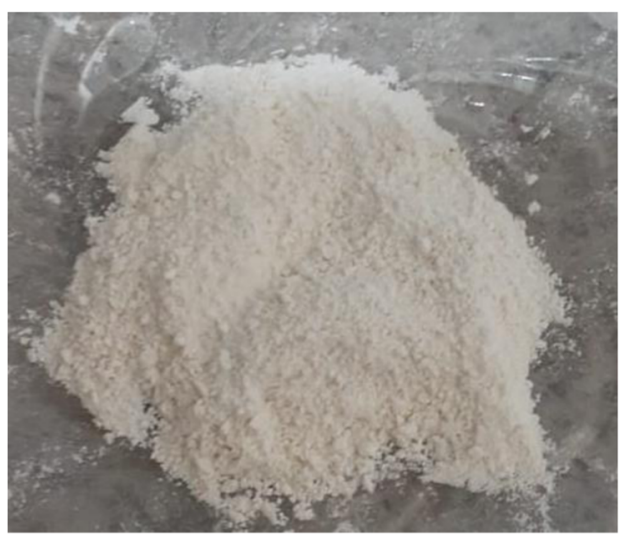

b

Fig. 1 Peuyeum starter culture "yeast tape", a whole and b pounded starter

\section{The history and authenticity of peuyeum}

Peuyeum or cassava tapay (Fig. 2) is a fermented Sundanese delicacy, made from cassava as the raw material [7, 8]. In Sundanese, peuyeum means "meuyeum" or "memeram," which stands for ripening, because in cassava manufacturing, it is ripened over a period of time known as incubation-the name comes from its processing method. Generally, peuyeum is known as "Peuyeum Bandung," with Bandung being the capital city of West Java. Food names may be influenced by the areas from which they are produced, where sometimes, inserting the name of an area into a product name as a brand becomes an attractive selling point [7]. The primary raw material for peuyeum is cassava, which is easy to find in West Java. Since West Java has fertile lands, it is not surprising that one of the people's primary livelihoods is farming. Moreover, the abundant cassava production led people to think about processing it into a saleable product. Several places in West Java, such as the villages of Citatah and Cimenyan [9-11], are considered peuyeum production centers (Bandung City and Bandung Regency), and they have copious availability of cassava. Since 1980, Citatah Village has been known as a producer of peuyeum. According to the local people, initially, the making process of peuyeum was introduced by the residents of Bendul-Purwakarta, who were trying to make a living in Citatah. As time passed, peuyeum was developed and known by its surrounding community, such that now, the village is known as one of the top producers of peuyeum in West Java. Presently, anyone can make the peuyeum because the starter cultures are easily available in the market.

\section{The philosophy of peuyeum}

Food is recognized as a symbol of civilization because eating is part of the daily activities of humans. Long ago, humans could only eat what was available in nature. But now, humans can choose what to eat and how to process it $[12,13]$. Eating habits as a culinary activity involve belief in the function of eating, include liking it or not, wisdom, beliefs, taboos, and assumptions related to food procurement, processing, distribution, and consumption $[14,15]$. In short, food is a foundational cultural element which is attached to various other elements. The role of food in culture is that of a prominent activity that determines social interactions related to belief and religion, determines the shape or pattern of the economy, and directs most activities of human daily life [16]. Local food in the archipelago contains a noble philosophy that has been passed down from generation to generation as the source and guide for Indonesian people's lives. Some of the noble values behind traditional food are, for example, solidarity, mutual cooperation, respect for diversity, respect for fellow humans, nature and its creators, and so on [13]. Food is not only to meet human needs but is also very closely related to culture, including technology, social organization, and public trust.

Philosophically, peuyeum represents social ties, group solidarity, peace of mind, and language symbolism. Food has no meaning unless it is seen within the context of its culture or network of social interactions. Peuyeum is the representation of social ties, meaning that the Sundanese can bind socially and emotionally with it. This traditional Sundanese food has existed since before Indonesia achieved independence, or approximately from the tail end of the nineteenth century. Since the reign of R.A.A. Marta Nagara (1893-1918), Dalem Bandung mostly planted cassava to be used as aci or tapioca flour, which was exported to the Dutch. In West Javanese society, the art to expressing and composing words in poetry is called pupuh. There is a pupuh which states "pupuh magatru peuyeum sampeu," meaning the 


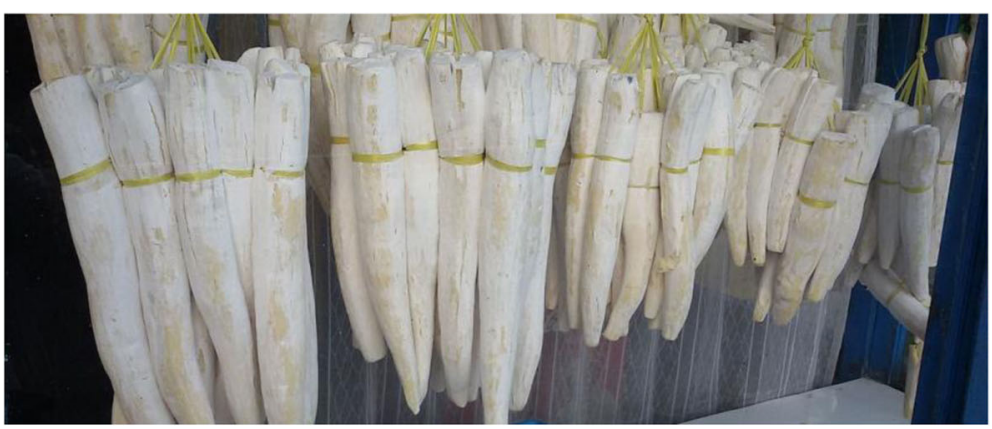

a

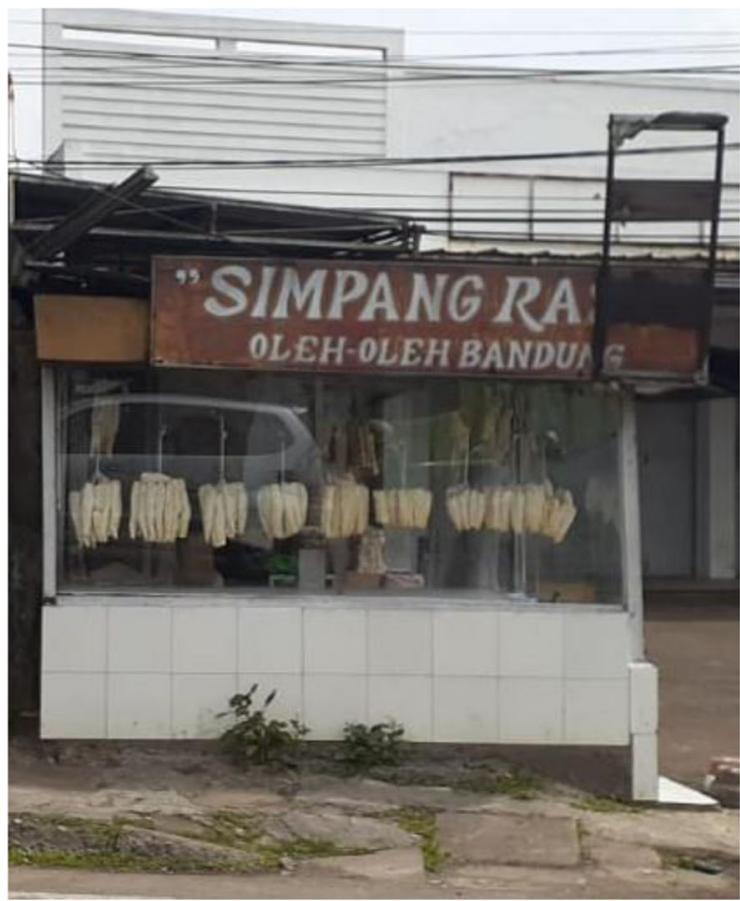

b

Fig. 2 a [6]. b Peuyeum is usually hung to attract consumer interest and it is sold in small stalls on the side of the road

location at which to use teak leaves to wrap the peuyeum. Moreover, peuyeum holds great symbolic importance for the young men who joined Tentara Rakyat (People's Army) and fought guerrilla and frontal in the national war of which was born the incident of Bandung Lautan Api. This incident is a historical event for Bandung and peuyeum meant much to them. But on the one hand, peuyeum is deemed flabby and not enthusiastic when facing enemies. Making peuyeum is considered a habit of the past that these youth members would participate in to show expressions of group solidarity. Consuming peuyeum was part of the sense of solidarity at that time. If the Sundanese were away from their country or far from their homeland, getting a peuyeum served by other Sundanese certainly added a sense of solidarity and the servers were considered brothers. Thus, solidarity is not only established by language but also food, implying that it can create a sense of brotherhood. Another function of peuyeum is for mental peace. It is believed that if a menstruating woman eats peuyeum, it can facilitate the discharge of menstrual blood. Psychologically, it can help calm a woman's soul. During menstruation, some women experience menstrual pains; therefore, they need physical and mental help for themselves which is why parents offer peuyeum to their children as a solution to relieve the pain caused by menstruation. As knowledge about the microbiome increases, including its relationship to mental health (e. g., anxiety and depression), it becomes clearer that there is a link between the resident microbes and many aspects of human physiology. The consumption of fermented foods is particularly relevant to research that links 
traditional dietary practices with positive mental health. The microbiota within fermented foods can reduce inflammation and oxidative stress, at least to some degree. Properly controlling the fermentation process can often strengthen the specific nutrients and phytochemical content of the food, which are linked to mental health [17]. However, this needs to be proven scientifically. The ancestral beliefs still exist today, but should be considered alongside modern knowledge, technology, and religious beliefs which can change people's point of views.

\section{The fermentation process of peuyeum}

Fermentation is a metabolic process in which microbial enzymes cause chemical changes within the organic substrates. This process helps prolong the shelf life of food so that it is not easily damaged, especially in tropical countries such as Indonesia [18]. Peuyeum is a traditional food that is produced through a fermentation process of carbohydrates or starchy foods [19]. Since peuyeum is produced traditionally, there is no set standard for the production process or for the product [11]. Peuyeum starter culture or yeast tapay consists of a consortium of fungi, yeast, and bacteria, where all three have their respective roles in developing the taste and aroma of peuyeum. The peeled and washed cassava is boiled until it is half-cooked. This boiling process aims to soften the cassava tissue to facilitate microbial penetration. The cassava is then drained and dried before being evenly coated with the starter culture covering the surface. Subsequently, the cassava is tightly wrapped and stored for approximately $48-72 \mathrm{~h}$ at room temperature. This wrapping and storage process is carried out because peuyeum fermentation is anaerobic. This process (Fig. 3) ceases when the ethanol levels rise to the point where microbial cells can no longer tolerate it. The high ethanol content inhibits fungal growth, leading to a condition where only alcohol-tolerant microbes can grow. If harvested at the right time, peuyeum will have a distinctive taste, which is sweet and slightly sour, with the aroma of alcohol [20].

Tapay starter or yeast tapay is a dry starter culture made from a mix of rice flour, spices, and water or sugarcane extract [4]. Yeast is a microbial inoculum or starter that plays a role in the fermentation process, generally working in anaerobic conditions to produce alcohol and $\mathrm{CO}_{2}[21,22]$. The inoculum is the main source

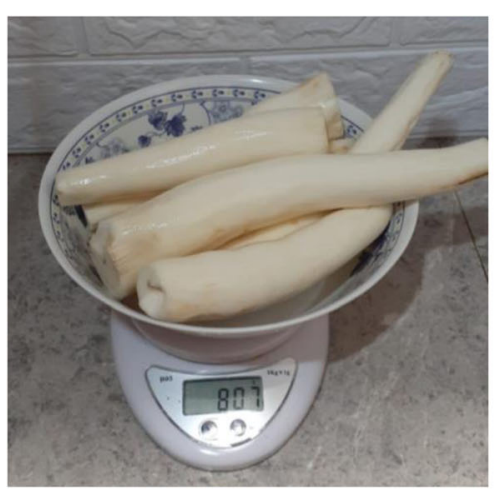

a

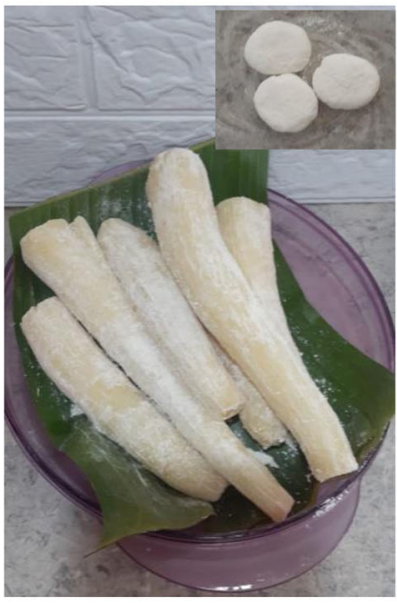

c

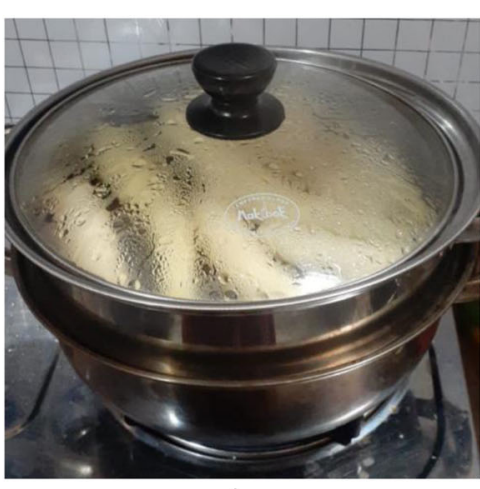

b

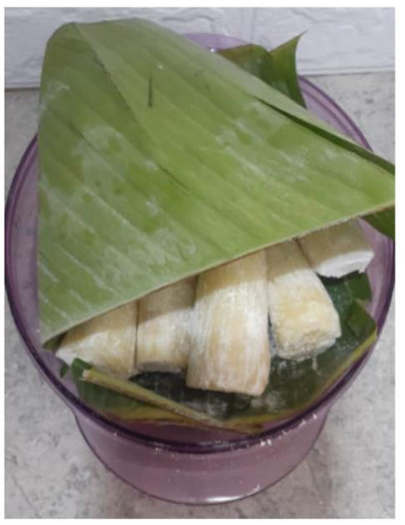

d

Fig. 3 Fermentation process of cassava: a peeling and washing, b boiling, c culture starter inoculation, and $\mathbf{d}$ incubation 
of active microorganisms in fermentation dough and is responsible for the organoleptic quality of cassava tapay products. This process also helps the texture of the peuyeum become soft and tender [5]. Saccharomyces cerevisiae is a yeast that can metabolize without oxygen, but, in the presence of oxygen, can also perform respiration, which leads to oxidizing sugar into $\mathrm{CO}_{2}$ and water [21]. Microbes play an important role in forming the taste of the foods produced through the fermentation process $[4,19]$. The peuyeum fermentation process begins with the hydrolysis of the starch to glucose by the amylase enzyme produced by the fungi, yeast, or amylolytic bacteria. The result of the breakdown of starch by the amyloglucosidase can be seen in the form of glucose molecules in what is called the saccharification stage. During the fermentation process, A. rouxii and C. beverwijkse hydrolyze starch into sugar, following which, in the alcohol formation, S. cerevisiae ferments the sugar, while Wickerhamomyces anomalus and C. berverwijkiae together develop the aroma of ester in tapay [12]. Apart from mold and yeast, microorganisms that are also found on tapay are bacteria such as lactic acid bacteria (LAB) and acetic acid bacteria (AAB) $[19,23,24]$. LAB can produce metabolites that produce taste and texture [25], and the alcohol, as a result of the breakdown of glucose by yeast, is converted into acetic acid under aerobic conditions.
In general, the biochemical changes during the fermentation process of cassava basically include four stages. First, in the enzymatic hydrolysis process, starch molecules are broken down into dextrins and simple sugars. Second, the sugars formed are then converted into alcohol. Third, the alcohol is then converted into organic acids by LAB through the alcohol oxidation process. Fourth, some of the organic acids react with the alcohol to form esters which lend the distinctive taste to peuyeum [26].

The fermentation process of cassava tapay must be done optimally. The duration of fermentation affects the moisture, glucose, and organoleptic content of cassava tapay [27]. Apart from choosing high-quality cassava raw materials, the process of making cassava tapay must be correct. The starter culture used should be of high quality because it is the main ingredient in the tapay-making process. Hygienic processing is essential to avoid contamination that may hinder product formation. The temperature during fermentation should also be focused on because it can affect the duration, fermentation rate, and quality of the final product. The stripping and cutting of cassava must be done using hygienic tools, safe containers, and keeping in mind food grade. Moreover, the room and worker's hygiene and sanitation must also be considered properly [28].

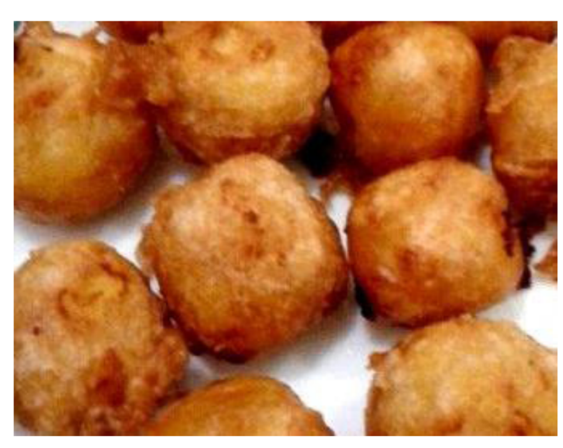

a

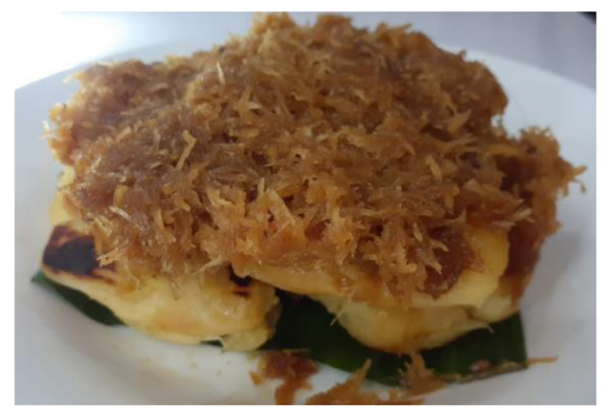

C

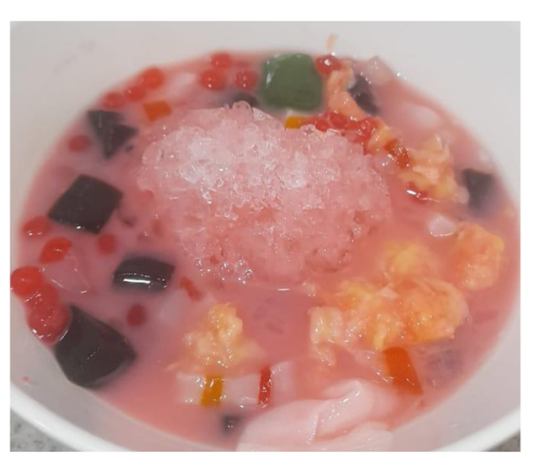

b

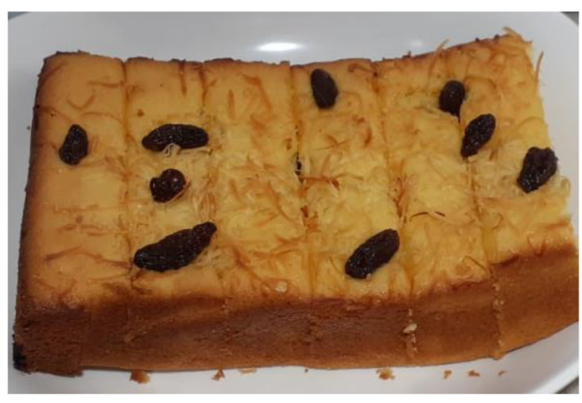

d

Fig. 4 Derivative products of Peuyeum Bandung: a fried peuyeum [29], b mixed fruit ice dessert, c colenak, and $\mathbf{d}$ peuyeum cake 


\section{The derivative products of peuyeum}

Peuyeum can be consumed directly or processed into other derivative products (Fig. 4). A simple processing is frying with a layer of flour called "peuyeum goreng" (fried peuyeum). Usually, fried peuyeum is served in the morning or evening accompanied by unsweetened tea. This type of food is easy to find because it is widely sold by street vendors. Another processing is serving it by adding sugar and coconut milk; this is called kolak. Kolak is usually served during the month of Ramadan, a glorious month for Muslims, the largest religion in Indonesia. Besides that, it can be served as an ingredient in fruit mixed ice, a drink that combines various kinds of fillings in the form of jellies, fruits, syrups, and ice shavings. This drink can be found in every restaurant and with a street vendor. Moreover, there are other peuyeum derivative products that are also West Java's local specialties, one of which is called colenak. Colenak is an acronym for "dicocol enak" (dip delightfully), which is eating it by dipping it into spices that come in the form of palm sugar and grated coconut. Colenak has a better shelf life than peuyeum because it is first baked (some are steamed). Peuyeum that has been roasted/ steamed is given a topping in the form of enten-enten-a palm sugar solution mixed with grated coconut. Apart from being a derivative product, cassava tapay is also used as a substitute for sugar in cake products [30]. In current product development, there are other types of processed products from peuyeum, which are peuyeum cake, also known as Prol Tape. Peuyeum cake is a semimoist food item that has a sweet taste due to the cassava and wheat flour. It is quite popular amongst the public and is one of the food products of high economic value [31]. In other words, apart from being eaten directly, the process of involving peuyeum into other products also lends to the origins of the characteristics of local foods.

\section{Conclusion}

In conclusion, it can be seen that the process of making peuyeum is passed down from generation to generation so that, to this day, it still exists and has become a local food of the West Java region. Peuyeum also stands for the fact that since time immemorial, the ancestors of this region have known and applied fermentation processing technology in cooking their food. The name of the peuyeum starter culture, ragi tape, is already being used by the public, even though, from a scientific point of view, the culture does not only consist of yeast but is a mixture of mold and bacteria as well. Peuyeum derivative products are packaged both in traditional and modern ways, including fried peuyeum, colenak, mixed fruit ice, and tapay cake, which are spread throughout Indonesia. In addition, peuyeum philosophically represents social ties and a sense of group solidarity, especially when the people of West Java were away from their homeland, they found a sense of brotherhood when meeting fellow villagers and sharing this food. Moreover, peuyeum carries as host of beliefs passed down through ancestors which help provide peace of mind and results in this food transcending to become a symbolic language.

\author{
Acknowledgements \\ Not applicable. \\ Author's contributions \\ The author writes and completes the final manuscript. The author read and \\ approved the final manuscript.
}

Funding

Not applicable.

Availability of data and materials

Not applicable.

\section{Declarations}

Competing interests

The author declares that there are no competing interests.

Received: 17 March 2021 Accepted: 3 May 2021

Published online: 13 May 2021

\section{References}

1. SSulastri E. In Organoleptik Tape Singkong (Manihot utillisima) dengan Penambahan Ekstrak Daun Katuk (Sauropus androgynus) (Thesis). Surakarta, Central Java: Universitas Muhammadiyah Surakarta; 2013. http://eprints.ums.ac.id/28001/.

2. Marjoko A, Hersoelistyorini W. Daya Terima dan Kadar Alkohol pada Tape Kulit Singkong Berdasarkan Variasi Jumlah Ragi. J Pangan Dan Gizi. 2011;02(04):47-58.

3. Fatmawati F, Abdillah MN, Fatmasari A, Mulyaningsih YD. Screening and identification of xylanase enzyme-producing bacteria in peuyeum cassava with 16S rRNA gene marker method. J Kartika Kimia. 2019;2(1):37-43.

4. Dirayati D, Gani A, Erlidawati E. Pengaruh Jenis Singkong dan Ragi Terhadap Kadar Etanol Tape Singkong. J IPA Pembelajaran IPA. 2018;1(1):26-33. https://doi.org/10.24815/jipi.v1i1.9461.

5. Hasanah H, Jannah A, Fasya AG. Pengaruh Lama Fermentasi Terhadap Kadar Alkohol Tape Singkong (Manihot utilissima Pohl). Alchemy. 2013;2(1):68-79. https://doi.org/10.18860/al.v0i0.2294.

6. Okkisafire, 2016. Tapai singkong. https://id.wikipedia.org/wiki/Berkas: Peuyeum.jpg. Accessed 16 Mar 2021

7. Isnendes R. Peuyeum Bandung Makanan Tradisional yang Terkenal (Conference). Yogyakarta: Seminar Folklor Internasional; 2013.

8. Nurahayu H. Peuyeum Bandung. Bandung: Lekkas Bandung; 2017.

9. Hidayanti AD, et al. Produksi Peuyeum minangka Pakasaban Masarakat Desa Citatah (Thesis). Bandung: Jurusan Pendidikan Bahasa Daerah FPBS UPI; 2012.

10. Ridwanto M. Eksistensi Sentra Industri Peuyeum di Kecamatan Cimenyan Kabupaten Bandung (Thesis). Bandung, West Java: Universitas Pendidikan Indonesia; 2013. http://repository.upi.edu/2786/.

11. Rengganis D, Mukti GW, Deliana Y, Esperanza D. Model Bisnis Olahan Singkong Pada Usaha Peuyeum Abbas Sawargi Kecamatan Cimenyan Kabupaten Bandung. J Pemikiran Masyarakat IImiah Berwawasan Agribisnis. 2018;4(2):121-38. https://doi.org/10.25157/ma.v4i2.1174.

12. Hasanah U, Ratihwulan, H, Nuraida L. Sensory profiles and lactic acid bacteria density of tape ketan and tape singkong in Bogor. AgriTECH.2018; 38(3):265-272. doi: https://doi.org/10.22146/agritech.30935, 2019

13. Setiawan R. Memaknai Kuliner Tradisional di Nusantara: Sebuah Tinjauan Etis Rudi Setiawan. Respons, Gabriele W.2016;01:113-140. http://ejournal.atmaja ya.ac.id/index.php/response/article/download/527/194/. Accessed 30 Jan 2021.

14. Wigna W, Khomsan A. Kearifan Lokal dalam Diversifikasi Pangan. Pangan. 2011;20(3):283-93.

15. Yevita N. Kajian Makanan Dalam Perspektif Antropologi. J Antropol. 2017; 19(1):1-10. 
16. Fadhilah A. Budaya Pangan Anak Singkong dalam Himpitan Modernisasi Pangan: Eksistensi Tradisi Kuliner Rasi (Beras Singkong) Komunitas Kampung Adat Cireundeu Leuwi Gajah Cimahi Selatan Jawa Barat. Al-Turas. 2014; 20(XX):13-30.

17. Selhub EM, Logan AC, Bested AC. Fermented foods, microbiota, and mental health: ancient practice meets nutritional psychiatry. J Physiol Anthropol. 2014;33(1):2. https://doi.org/10.1186/1880-6805-33-2.

18. Nuraida L. A review: Health promoting lactic acid bacteria in traditional Indonesian fermented foods. Food Science and Human Wellness. 2015;4(2): 47-55. https://doi.org/10.1016/j.fshw.2015.06.001.

19. Barus T, Wijaya N. Mikrobiota Dominan dan Perannya dalam Cita Rasa Tape Singkong Dominant microbiota and their role in flavor of cassava tape Pendahuluan Metode Penelitian. J Biota. 2011;16(2):354-61.

20. Fahmi N. and Nurrahman. Kadar Glukosa, Alkohol dan Citarasa Tape Onggok Berdasarkan Lama Fermentasi. J Pangan dan Gizi. 2011;02(03):25-42.

21. Walker GM, Stewart GG. Review: Saccharomyces cerevisiae in the production of fermented beverages. MDPI Beverages. 2016;2(4):30. https://doi.org/10.33 90/beverages2040030.

22. Nurhartadi, E \& Rahay, E.S. Isolasi dan Karakterisasi Yeast Amilolitik dari Ragi Tape. J Teknol Hasil Pertanian. 2011; IV:1.

23. Nuraida L, Owens JD. Sweet, sour, alcoholic solid substate fungal fermentations. In: Owens JD, editor. Indigenous fermented foods of Southeast Asia. Boca Raton: CRC Press; 2014. p. 137-55.

24. Sujaya IN, Nocianitri KA, Asano K. Diversity of bacterial flora of Indonesian ragi tape and their dynamics during the tape fermentation as determined by PCRDGGE. Int Food Res J. 2010;17:239-45.

25. Kumar AM, Murugalatha N. Isolation of Lactobacillus plantarum from cow milk and screening for the presence of sugar alcohol producing gene. J Microbiol Antimicrob. 2012;4(1):16-22. https://doi.org/10.5897/JMA11.083.

26. Made A. Tetap Sehat Dengan Produk Makanan Olahan. Surakarta: Tiga Serangkai; 2004.

27. Sahratullah JDSD, Zulkifli L. Pengaruh Konsentrasi Ragi Dan Lama Fermentasi Terhadap Kadar Air, Glukosadan Organoleptik Pada Tape Singkong. J Biol Tropis. 2017;17(1):43-52.

28. Moelyaningrum AD. Hazard Analysis Critical Control Point (HACCP) Pada Produk Tape Singkong Untuk Meningkatkan Keamanan Pangan Tradisional Indonesia. Indonesian J Health Sci. 2012;3(1):41-9.

29. Resep Peuyeum Goreng Isi Cokelat (In Bahasa). https://www.eresep.com/ resep/peuyeum-goreng-isi-cokelat. Accessed 16 Mar 2021

30. Gusnadi D. Analisis Uji Organoleptik Tapai Singkong Pada Produk Cookies Sevagai Upaya Meningkatkan Eksistensi Tapai Singkong di Kota Bandung. J Akrab Juara. 2019; 4(5): 73-80.

31. Putri S, Hersoelistyorini W. Kajian Kadar Protein, Serat, Hcn, Dan Sifat Organoleptik Prol Tape Singkong Dengan Substitusi Tape Kulit Singkong. J Pangan Dan Gizi. 2012;3(6):17-28.

\section{Publisher's Note}

Springer Nature remains neutral with regard to jurisdictional claims in published maps and institutional affiliations.

\section{Ready to submit your research? Choose BMC and benefit from:}

- fast, convenient online submission

- thorough peer review by experienced researchers in your field

- rapid publication on acceptance

- support for research data, including large and complex data types

- gold Open Access which fosters wider collaboration and increased citations

- maximum visibility for your research: over $100 \mathrm{M}$ website views per year

At BMC, research is always in progress.

Learn more biomedcentral.com/submissions 